\title{
Stereotactíg
}

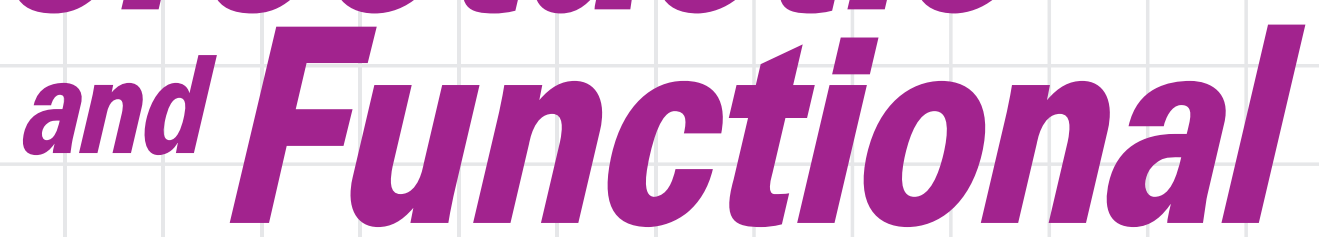

Neurosurgery

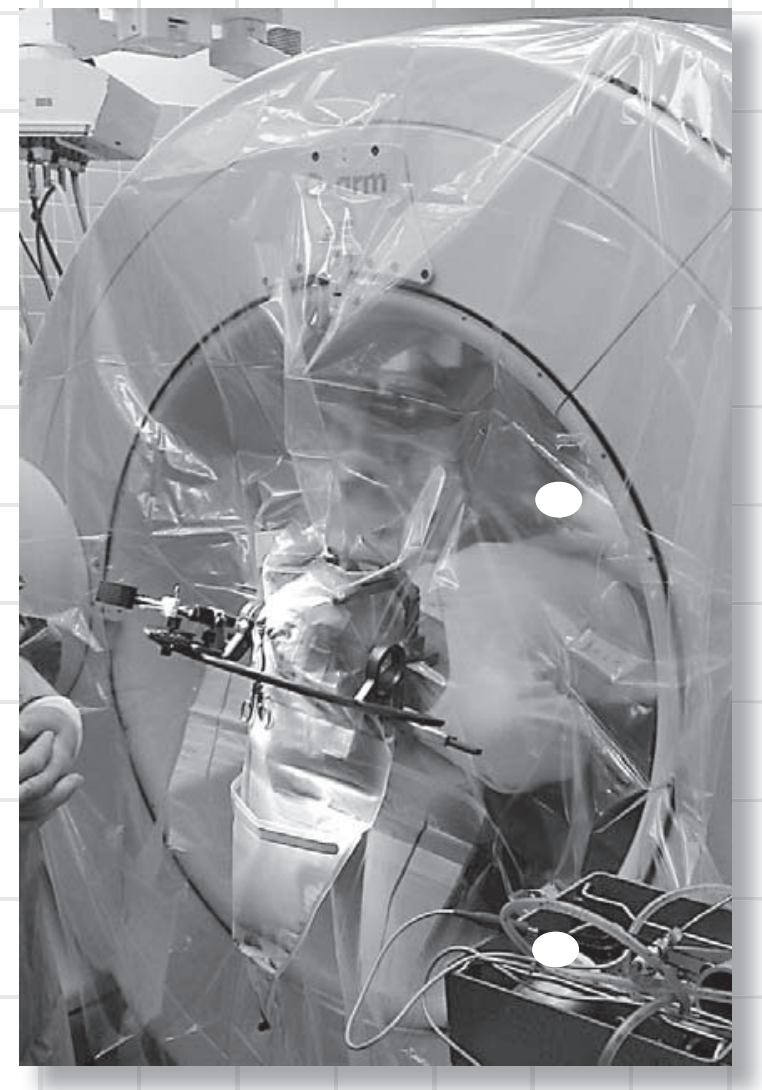




\title{
A current and thorough work on endoscopic skull base surgery
}

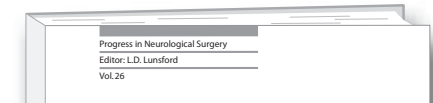

\section{Endoscopic Approaches} to the Skull Base

Edtors
A.B. Kassam
P.A. Gardner

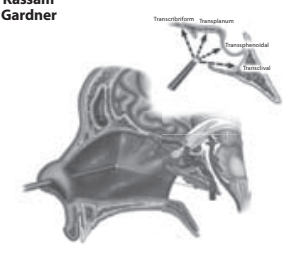

KARGER

\section{Endoscopic Approaches to the Skull Base}

\author{
Editors \\ Amin B. Kassam \\ Paul A. Gardner
}

During the last decade the endoscopic endonasal approach (EEA) to the skull base has become a very powerful method to add to the array of neurosurgical technologies. This volume provides a broad overview of the role of transnasal approaches in a wide spectrum of skull base diseases. It starts with a historical perspective of the evolution from the microscope to the endoscope in endonasal surgery and then explores in depth the principles and techniques of the various methods. Discussed are topics based on anatomical boundaries: pituitary fossa to the suprasellar space to the cavernous sinus, clivus and the anterior cranial fossa. Access to the infratemporal and posterior fossae via both the endoscopic endonasal and the retrosigmoid approaches are reviewed. In addition, the critical topic of reconstruction following 'minimally invasive' skull base surgery and finally the learning curve and complications associated with the applications of these new and exciting approaches are discussed.

This volume will provide the latest knowledge to help neurosurgeons, otolaryngologists, head and neck surgeons as well as craniofacial surgeons understand the applications and practice of this important technique.

\section{Contents}

Editor's Note: Lunsford, L.D.

Historical Perspectives: Cappabianca, $P_{\text {.; }}$ Esposito, F.; de Divitiis, 0 .

Advantages of the Endoscope and Transitioning from the Microscope to the Endoscope for Endonasal Approaches: Jagannathan, J.; Laws, E.R.; Jane, J.A., Jr.

Principles of Endoneurosurgery: Kassam, A.B.; Gardner, P.A.; Prevedello, D.M.; Snyderman, C.H.; Carrau, R.L.

Otolaryngology Head and Neck Surgery Approaches: Janjua, A.; Naseri, I.; Witterick, I.; Vescan, $A$.

Sellar/Tuberculum Approach: Cappabianca, $P_{\text {.; }}$ Cavallo, L.M.; Esposito, I.; Solari, D.

Endoscopic Approach for Pituitary Tumors: Louis, R.G.; Pouratian, N.; Jane, J.A., Jr.

Endoscopic Endonasal Approach for Olfactory Groove Meningiomas: Gardner, P.A.; Vescan, A.; de Almeida, J.R.; Janjua, A.; Kassam, A.B.; Prevedello, D.M.; Carrau, R.L.; Snyderman, C.H. Endoscopic Anterior Skull Base Resection for Esthesioneuroblastoma: Zanation, A.M.; Casiano, R.R.; Carrau, R.L.; Snyderman, C.H.; Kassam, A.B.; Gardner, P.A.; Prevedello, D.M.; Mitchell, C.A.; Mintz, A.
Endoscopic Approaches to the Skull Base: The Coronal Plane: Prevedello, D.M.; Kassam, A.B.; Otto, B.A.; Ditzel Filho, L.F.S.; de Lara, D.; Carrau, R.L.

Cavernous Sinus: Endoscopic Endonasal Approaches: Frank, G.; Pasquini, E.

Expanded Pure Endoscopic Endonasal Approach for Clival Lesions: Dehdashti, A.R.; Omahen, D.A.; Gentili, $\boldsymbol{F}$.

Endoscopic Endonasal Approach to the Odontoid and Craniocervical Junction: Gardner, P.A.; Tormenti, M.J.; Kassam, A.B.; Spiro, R.M.; Prevedello, D.M.; Carrau, R.L.; Snyderman, C.H.

Endoscopic Reconstruction of Anterior Skull Base Defects: Zanation, A.M.; Carrau, R.L.; Snyderman, C.H.; Kassam, A.B.; Gardner, P.A.; Prevedello, D.M.; Mintz, A.H.

Management of Complications of Endonasal Cranial Base Surgery: Snyderman, C.H.; Pant, H.; Gardner, P.A.; Carrau, R.L.; Prevedello, D.M.; Kassam, A.B.

Endoscopic Approaches to the Cerebellopontine Angle: Pieper, D.R.; Bojrab, D.

Endoscope-Assisted Skull Base Surgery: de Paiva Neto, M.A.; Dusick, J.R.; Fatemi, N.; Kelly, D.F.

The Learning Curve for Endonasal Surgery of the Cranial Base: A Systematic Approach to Training: Snyderman, C.H.; Pant, H.; Kassam, A.B.; Carrau, R.L.; Prevedello, D.M.; Gardner, P.A.

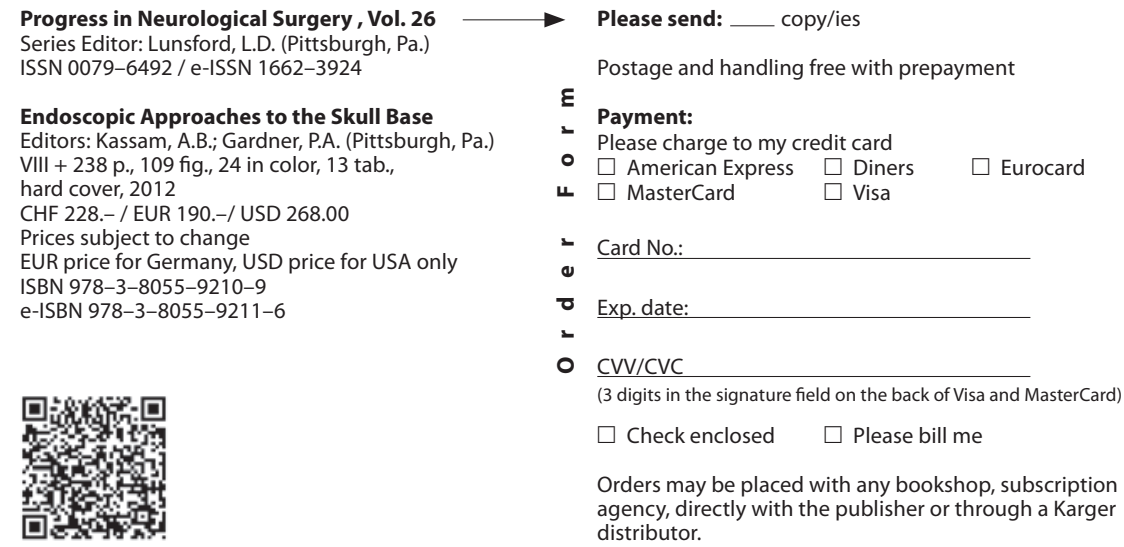

Please send: __ copy/ies

Postage and handling free with prepayment

$\boldsymbol{\varepsilon}$ Payment:

Please charge to my credit card

- $\square$ American Express $\square$ Diners $\square$ Eurocard

4 MasterCard

- Card No.

๑

Exp. date:

- CVV/CVC

(3 digits in the signature field on the back of Visa and MasterCard)

$\square$ Check enclosed $\square$ Please bill me

Orders may be placed with any bookshop, subscription agency, directly with the publisher or through a Karger distributor.

Fax: +41613061234

S. Karger AG, P.O. Box, CH-4009 Basel (Switzerland)

E-Mail orders@karger.ch,www.karger.com

Name/Address: 
Official Journal of

\begin{tabular}{ll} 
World Society for \\
$\begin{array}{l}\text { Stereotactic and } \\
\text { Functional Neurosurgery }\end{array}$ \\
$\begin{array}{ll}\text { American Society for } \\
\text { Stereotactic and } \\
\text { Functional Neurosurgery }\end{array}$ \\
\hline
\end{tabular}

\section{Editor}

David W. Roberts, Lebanon, N.H.

\section{Associate Editor}

Philip L. Gildenberg, Houston, Tex.

\section{Assistant Editor}

Melissa D. Robb, Lebanon, N.H.

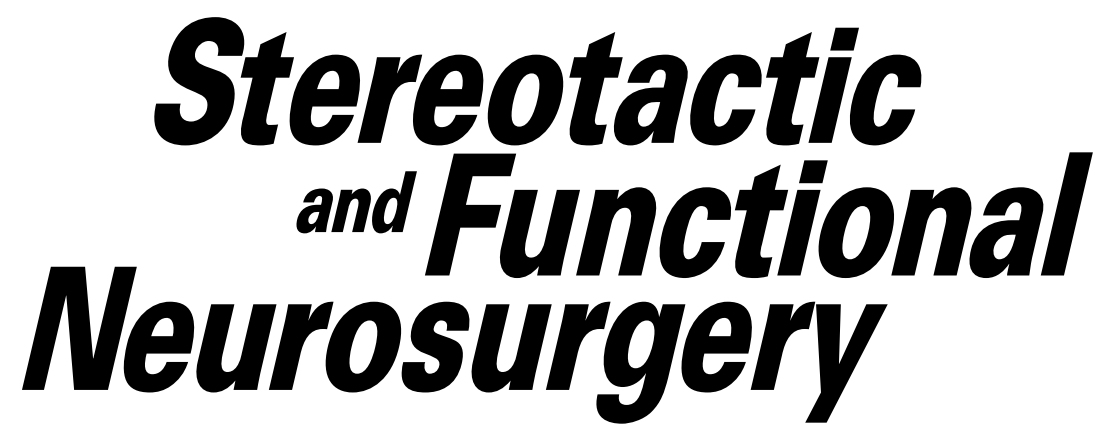

Founded 1938 as 'Confinia Neurologica' by E.A. Spiegel

Continued 1975-1988 as 'Applied Neurophysiology'

\section{Editorial Board}

A. Abosch, Minneapolis, Minn. M.L.J. Apuzzo, Los Angeles, Calif. T. Aziz, Oxford

N.M. Barbaro, Indianapolis, Ind.

A.L. Benabid, Grenoble

G. Broggi, Milan

B.P. Brophy, Adelaide

K.J. Burchiel, Portland, Oreg.

J.W. Chang, Seoul

G.R. Cosgrove, Providence, R.I.

W.A. Friedman, Gainesville, Fla.

R.E. Gross, Atlanta, Ga.

T. Hori, Tokyo

M.G. Kaplitt, New York, N.Y.

Y. Katayama, Tokyo

P.J. Kelly, New York, N.Y.
D.S. Kondziolka, Pittsburgh, Pa. J.K. Krauss, Hannover K.H. Lee, Rochester, Minn.

A. Lozano, Toronto, Ont. L.D. Lunsford, Pittsburgh, Pa. F. Piedimonte, Buenos Aires V. Rajshekhar, Vellore J. Regis, Marseille A.R. Rezai, Columbus, Ohio M. Schulder, Manhassett, N.Y. M.P. Sindou, Lyon K.V. Slavin, Chicago, Ill.

T. Taira, Tokyo

Z. Tian, Beijing

F. Velasco Campos, Mexico City

O. Vilela Filho, Goiânia
Printed in Switzerland on acid-free and non-aging paper (ISO 9706) by Reinhardt Druck, Basel
Appears bimonthly: 1 volume per year (6 issues) 


\section{Stereotactic and Functional Neurosurgery}

\section{Submission}

Only original papers written in English are considered and should be submitted using the online submission website at:

\section{www.karger.com/sfn}

Should you experience any problems with your submission, please contact:

sfn@karger.ch
Professor David W. Roberts
Section of Neurosurgery
Dartmouth Medical Center
1, Medical Center Drive
Lebanon, NH 03756-0001 (USA)
Tel. +1 $6036508734 / 6$
Fax +1 6036507911

\section{Conditions}

All manuscripts are subject to editorial review. Manuscripts are received with the explicit understanding that they are not under simultaneous consideration by any other publication. Submission of an article for publication implies the transfer of the copyright from the author to the publisher upon acceptance. Accepted papers become the permanent property of 'Stereotactic and Functional Neurosurgery' and may not be reproduced by any means, in whole or in part, without the written consent of the publisher. It is the author's responsibility to obtain permission to reproduce illustrations, tables, etc. from other publications.

\section{Arrangement}

Title page: The first page of each paper should indicate the title, the authors' names, the institute where the work was conducted, and a short title for use as running head.

Full address: The exact postal address of the corresponding author complete with postal code must be given at the bottom of the title page. Please also supply phone and fax numbers, as well as e-mail address.

Key words: Please supply 3-10 key words in English that reflect the content of the paper.

Abstract: Each paper needs an abstract of up to 200 words. It should be structured as follows:

Background: What is the major motive that prompted the study?

Objectives: What is the purpose of the study?

Methods: How was the study done?

Results: $\quad$ Most important findings

Conclusions: Most important conclusions

Footnotes: Avoid footnotes.

Tables and illustrations: Tables and illustrations (both numbered in Arabic numerals) should be prepared on separate pages. Tables require a heading and figures a legend, also prepared on a separate page. For the reproduction of illustrations, only good drawings and original photographs can be accepted; negatives or photocopies cannot be used. Due to technical reasons, figures with a screen background should not be submitted. When possible, group several illustrations in one block for reproduction (max. size $180 \times 223 \mathrm{~mm}$ ) or provide crop marks. Electronically submitted $b / w$ half-tone and color illustrations must have a final resolution of 300 dpi after scaling, line drawings one of 800-1,200 dpi.

\section{Color Illustrations}

Online edition: Color illustrations are reproduced free of charge. In the print version, the illustrations are reproduced in black and white. Please avoid referring to the colors in the text and figure legends.

Print edition: Up to 6 color illustrations per page can be integrated within the text at CHF 800.- per page.

\section{References}

In the text identify references by Arabic numerals [in square brackets]. Material submitted for publication but not yet accepted should be noted as 'unpublished data' and not be included in the reference list. The list of references should include only those publications which are cited in the text. Do not alphabetize; number references in the order in which they are first mentioned in the text. The surnames of the authors followed by initials should be given. There should be no punctuation other than a comma to separate the authors. Preferably, please cite all authors. Abbreviate journal names according to the Index Medicus system. Also see International Committee of Medical Journal Editors: Uniform requirements for manuscripts submitted to biomedical journals (www.icmje.org).

\section{Examples}

(a) Papers published in periodicals: Chatel J-M, Bernard $\mathrm{H}$, Orson FM: Isolation and characterization of two complete Ara h 2 isoforms cDNA. Int Arch Allergy Immunol 2003;131:14-18

(b) Papers published only with DOI numbers:

Theoharides TC, Boucher W, Spear K: Serum interleukin-6 reflects disease severity and osteoporosis in mastocytosis patients. Int Arch Allergy Immunol DOI: $10.1159 / 000063858$

(c) Monographs: Matthews DE, Farewell VT: Using and Understanding Medical Statistics, ed 3, revised. Basel, Karger, 1996.

(d) Edited books: DuBois RN: Cyclooxygenase-2 and colorectal cancer; in Dannenberg AJ, Dubois RN (eds): COX-2. Prog Exp Tum Res. Basel, Karger, 2003, vol 37, pp 124-137.

Reference Management Software: Use of EndNote is recommended for easy management and formatting of citations and reference lists.

\section{Digital Object Identifier (DOI)}

S. Karger Publishers supports DOIs as unique identifiers for articles. A DOI number will be printed on the title page of each article. DOIs can be useful in the future for identifying and citing articles published online without volume or issue information. More information can be found at www.doi.org.

\section{Supplementary Material}

Supplementary material is restricted to additional data that are not necessary for the scientific integrity and conclusions of the paper. Please note that all supplementary files will undergo editorial review and should be submitted together with the original manuscript. The Editors reserve the right to limit the scope and length of the supplementary material. Supplementary material must meet production quality standards for Web publication without the need for any modification or editing. In general, supplementary files should not exceed $10 \mathrm{MB}$ in size. All figures and tables should have titles and legends and all files should be supplied separately and named clearly. Acceptable files and formats are: Word or PDF files, Excel spreadsheets (only if the data cannot be converted properly to a PDF file), and video files (.mov, .avi, .mpeg).

\section{Author's Choice ${ }^{\mathrm{TM}}$}

Karger's Author's Choice ${ }^{\mathrm{TM}}$ service broadens the reach of your article and gives all users worldwide free and full access for reading, downloading and printing at www.karger.com. The option is available for a onetime fee of CHF 3000.-, which is a permissible cost in grant allocation. More information can be found at www.karger.com/authors choice.

\section{NIH-Funded Research}

The U.S. National Institutes of Health (NIH) mandates under the NIH Public Access Policy that final, peerreviewed manuscripts appear in its digital database within 12 months of the official publication date. As a service to authors, Karger submits the final version of your article on your behalf to PubMed Central. For those selecting our premium Author's Choice ${ }^{\mathrm{TM}}$ service, the usual embargo will be overriden, accelerating the accessibility of your work. More details on NIH's Public Access Policy are available at http://publicaccess. nih.gov/policy.htm.

\section{Self-Archiving}

Karger permits authors to archive their pre-prints (i.e. pre-refereeing) or post-prints (i.e. final draft post-refereeing) on their personal or institution's servers, provided the following conditions are met: Articles may not be used for commercial purposes, must be linked to the publisher's version, and must acknowledge the publisher's copyright. Authors selecting Karger's Author's Choice ${ }^{\mathrm{TM}}$ feature, however, are also permitted to archive the final, published version of their article, which includes copyediting and design improvements as well as citation links.

\section{Page Charges}

There are no page charges for papers of 5 or fewer printed pages (including tables, illustrations and references). Each additional complete or partial page is charged to the author at CHF 325.-. The allotted size of a paper is equal to approx. 16 double-spaced manuscript pages (including tables, illustrations and references).

\section{Proofs}

Unless indicated otherwise, proofs are sent to the corresponding author and should be returned with the least possible delay. Alterations other than the correction of printer's errors are charged to the author.

\section{Reprints}

Order forms and a price list are sent with the proofs. Orders submitted after the issue is printed are subject to considerably higher prices.

\section{KARGER}

Fax +4161306 1234 E-Mail karger@karger.ch www.karger.com
(C) 2012 S. Karger AG, Basel 


\section{Stereotactic and Functional Neurosurgery}

ISSN Print Edition: 1011-6125

ISSN Online Edition: 1423-0372

Journal Homepage: www.karger.com/sfn

Publication Data: 'Stereotactic and Functional Neurosurgery' is published 6 times a year. Volume 90 with 6 issues appears in 2012.

Copyright: (c) 2012 S. Karger AG, Basel (Switzerland). All rights reserved. No part of this publication may be translated into other languages, reproduced or utilized in any form or by any means, electronic or mechanical including photocopying, recording, microcopying, or by any information storage and retrieval system, without permission in writing from the publisher or, in the case of photocopying, direct payment of a specified fee to the Copyright Clearance Center.

Disclaimer: The statements, opinions and data contained in this publication are solely those of the individual authors and contributors and not of the publisher and the editor(s). The appearance of advertisements in the journal is not a warranty, endorsement, or approval of the products or services advertised or of their effectiveness, quality or safety. The publisher and the editor(s) disclaim responsibility for any injury to persons or property resulting from any ideas, methods, instructions or products referred to in the content or advertisements.
Subscription Rates: Subscriptions run for a full calendar year. Prices are given per year. Personal subscription

Print or Online

CHF 907.-

EUR 725--

USD 880.00

Print+Online combined CHF 955.-

EUR 763.-

USD 927.00

postage and handling (added to print and print+online)

CHF 40.80 Europe, CHF 60.00 Overseas

EUR 31.20

USD 56.40

Institutional subscription:

Print or Online

Print+Online combined

CHF 1813.

EUR 1450.-

CHF 1994.-

USD 1760.00

postage and handling (added to print and print+online)

CHF 51.- Europe, CHF 75.- Overseas

EUR 39.-

USD 70.50

Airmail surcharge: CHF 51.- / USD 48.00

Discount subscription prices:

Societies for Stereotactic and Functional

Neurosurgery are requested to apply for appropriate discounts.
Back Volumes and Single Issues: Information on availability and prices of single print issues and print or electronic back volumes can be obtained from Cus-

Bibliographic Indices: This journal is regularly listed in bibliographic services, including Current Contents ${ }^{\circledast}$.

Photocopying: This journal has been registered with the Copyright Clearance Center (CCC), as indicated by the code appearing on the first page of each article. For readers in the US, this code signals consent for copying of articles for personal or internal use, or for the personal or internal use of specific clients, provided that the stated fee is paid per copy directly to

Copyright Clearance Center Inc.

222 Rosewood Drive

Danvers, MA 01923 (USA)

A copy of the first page of the article must accompany payment. Consent does not extend to copying for general distribution, for promotion, for creating new works, or for resale. In these cases, specific written permission must be obtained from the copyright owner,

S. Karger AG, P.O. Box

CH-4009 Basel (Switzerland). tomer Service at service@karger.ch.
Subscription Orders:

Orders can be placed at agencies, bookstores, directly with the Publisher

\section{S. Karger AG}

Medical and Scientific Publishers

P.O. Box

CH-4009 Basel

Switzerland

(for courier services only:

Allschwilerstrasse 10

: +416130611 11

f: +41613061234

e: karger@karger.ch

w: www.karger.com
$\mathrm{CH}-4055$ Basel) or further Karger offices

or representatives:

Germany

S. Karger GmbH

Postfach

79095 Freiburg

Deutschland

(Hausadresse: Wilhelmstrasse 20A

79098 Freiburg)

$\mathrm{t}: \quad+49761452070$

e: information@karger.de

w: www.karger.de

Japan

Karger Japan, Inc

Shiba Daimon Asahi Bldg. 2F

1-2-23 Shiba Daimon

Minato-ku

Tokyo 105-0012

Japan

t: +81364356242

f: +81364356244

w: www.karger.jp f: +497614520714

e: publisher@karger.jp

Change of Address:

Both old and new address should be sent

to the subscription source.
USA

S. Karger Publishers, Inc.

26 West Avon Road

P.O. Box 529

Unionville, CT 06085

USA

Toll free: +18008285479

t: +18606757834

f: +18606757302

e: karger@snet.net

France

Librairie Médi-Sciences Sar

36, bd de Latour-Maubourg

75007 Paris

France

t: $+33(0) 145514258$

f: $+33(0) 145560780$

f: $+33(0) 145560780$

e: librairie@medi-sciences.

Gulf Council Countries, Iran,

Middle East, North Africa, Turkey

Trans Middle East International

Distribution Co. Ltd. (KaSha)

168 B, King Abdullah the 2nd Street

Daboog Building 2nd Floor

Daboog Area

P.O. Box 2376

Amman 11953

Jordan

t: +962 65153467

f: +96265411336

e: info@kasha.cc

w: www.KaShaonline.com
South East Asia, China and Taiwan Karger Regional Office (Malaysia)

CEO Suite Kuala Lumpur

Quill 7, 27th Floor

Jalan Stesen Sentral 5

KL Sentral

Kuala Lumpur 50470

Malaysia

t: +60327766803

f: +60327766999

e: service@karger.cn; r.chew@karger.cn

\section{Karger China}

10th Floor, Twin Towers (East)

B12 Jianguomenwai Avenue

Beijing 100022

China

t: +861051235033

$\mathrm{f:}+861051235122$

e: service@karger.cn; r.chew@karger.cn

w: www.karger.cn

India, Bangladesh, Sri Lanka

Medscience India

Plot No. 17, Yusuf Sarai Market

B.L. Glass Building, 2nd Floor

Sri Aurobindo Marg

India

t: +911146029633

f: +911146029634

c: +919891052128

e: medsci.india@gmail.com
New Delhi 110016

\section{KARGER}

Fax +41 613061234

E-Mail karger@karger.ch

www.karger.com

\section{(C) 2012 S. Karger AG, Basel}

The Journal Home Page is available at:

www.karger.com/sfn 


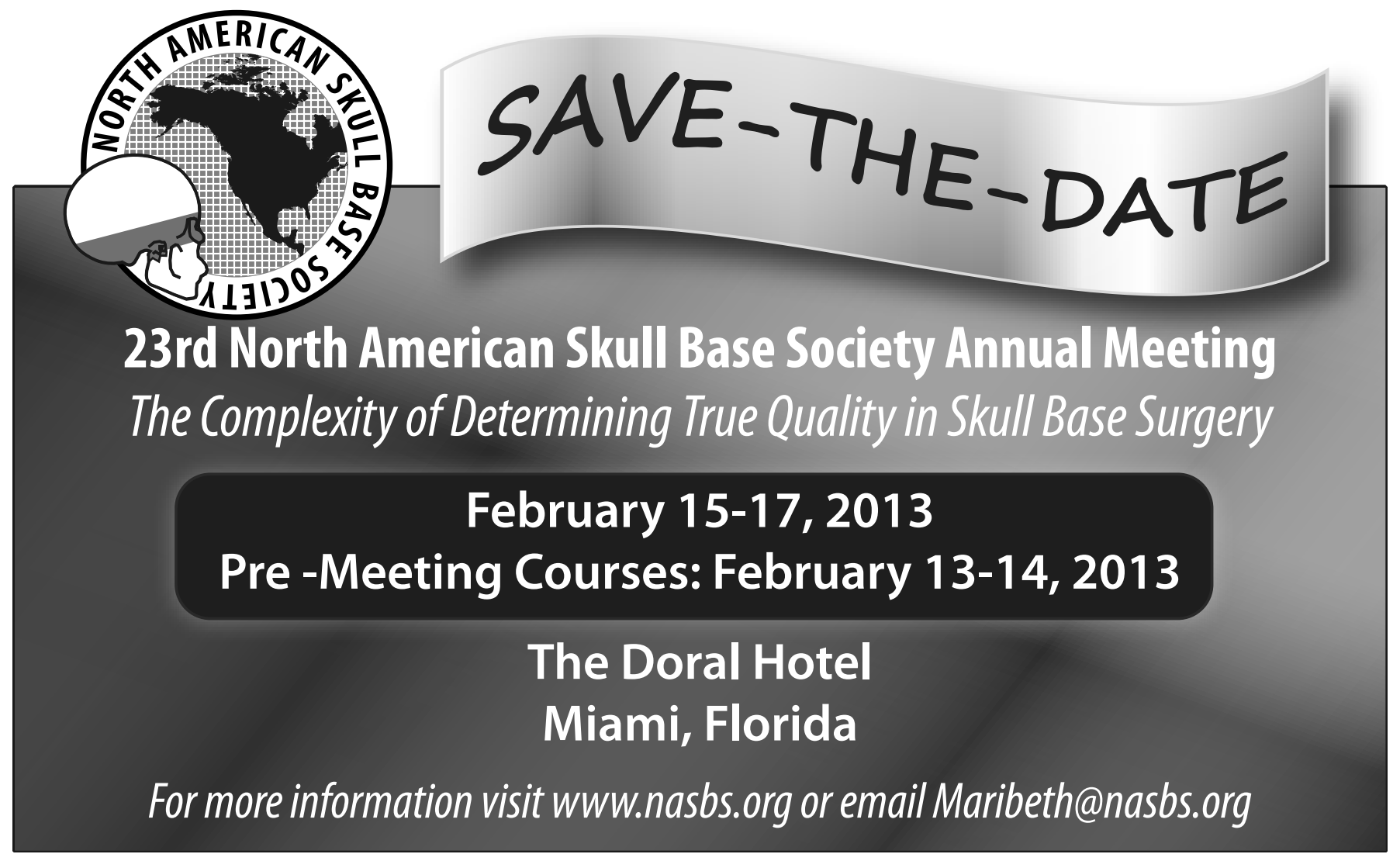

F13223

\section{A new vision to understanding medicine}

Handbook of Clinical Gender Medicine

Editors: Karin Schenck-Gustafsson (Stockholm), Paula R. DeCola, Donald W. Pfaff (New York, N.Y.), David S.Pisetsky (Durham N.C.)

In well-referenced chapters, experts cogently and concisely explain how the incorporation of gender issues into research can affect the medical understanding and treatment of heart disease, osteoporosis, arthritis, pain as well as malaria among other conditions.

This intriguing and unique medical textbook provides readers with a valuable new perspective on how to incorporate gender issues into the different branches of medicine.
Handbook of

Clinical Gender Medicine

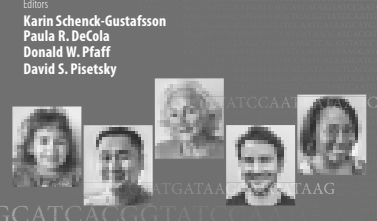

KARGER

More information and sample essays at:

www.karger.com/Gender_Medicine

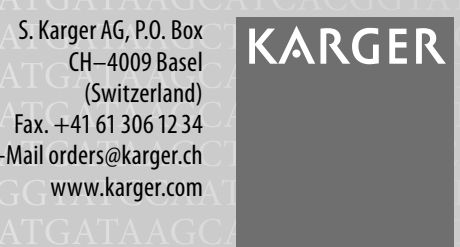

$X V I+522$ p., 62 fig., 4 in color, 63 tab., soft cover, 2012

CHF 69.- / EUR 51.- / USD 69.00

ISBN 978-3-8055-9929-0

e-ISBN 978-3-8055-9930-6

Prices subject to change

EUR price for Germany,

USD price for USA only 


\section{Contents}

See the journal website for contents

KARGER Basel $\bullet$ Freiburg $\cdot$ Paris $\bullet$ London $\bullet$ New York $\cdot$ New Delhi $•$ Bangkok Beijing $\cdot$ Tokyo $\cdot$ Kuala Lumpur $\cdot$ Singapore $\bullet$ Sydney 


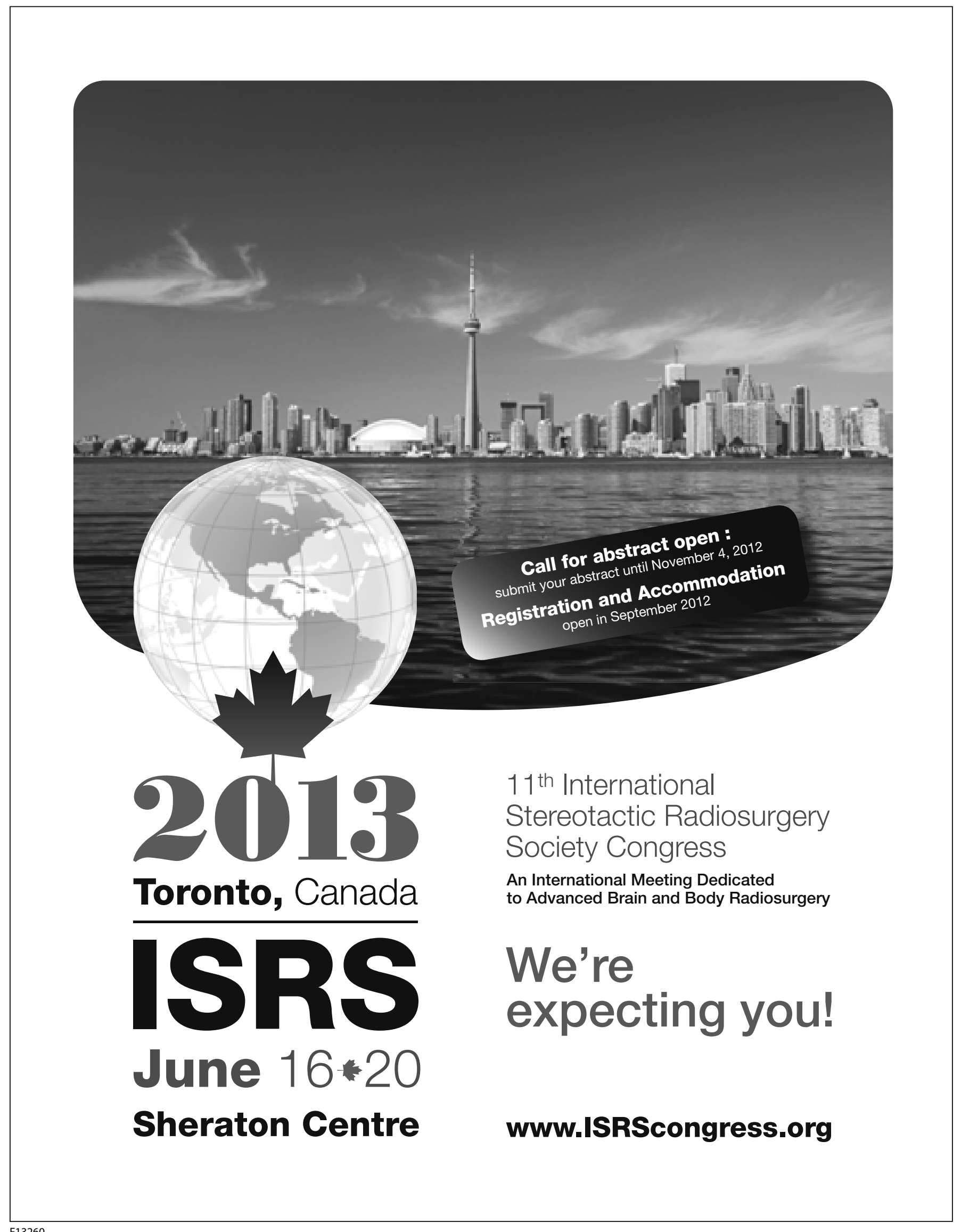


Save the Date! June 8-13

\section{INS 11th World Gongress}

Neuromodulation: Technology Transforming Chronic Illness Management
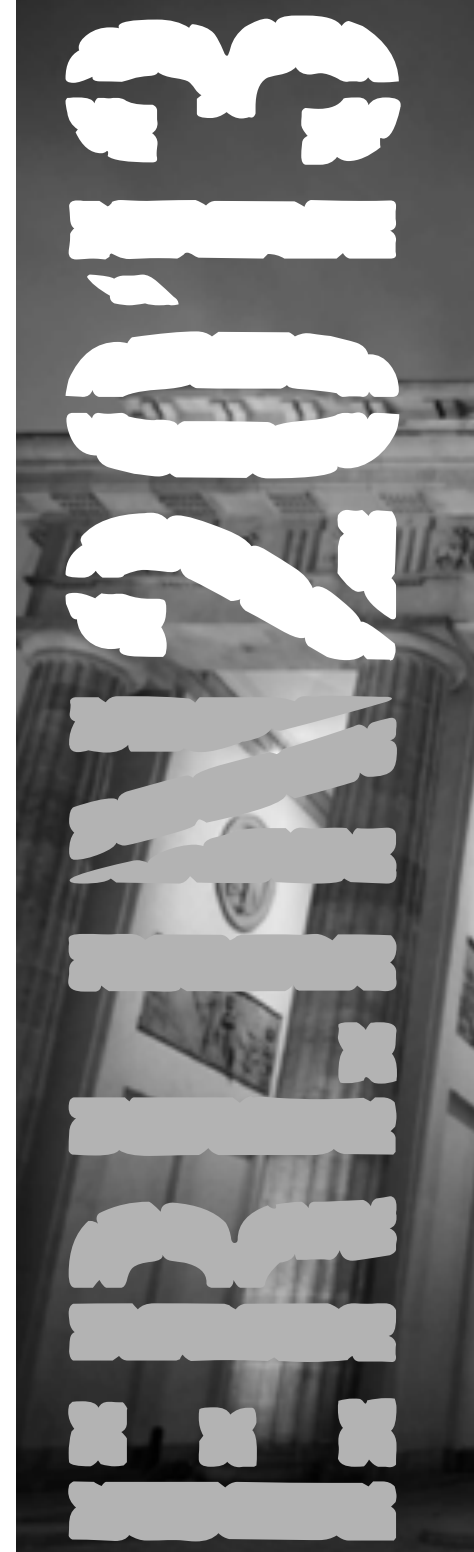
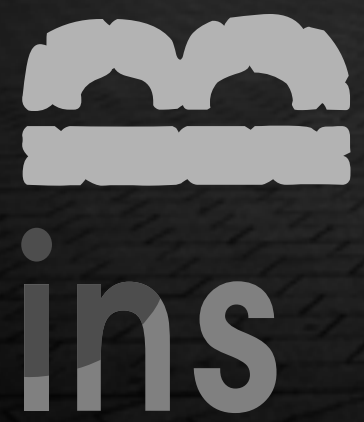

International

Neuromodulation

Society

\section{PRE-CONFERENGE}

Solving Problems at the Neural Interface; Innovations in Neuromodulation:

Bringing New ldeas to Market

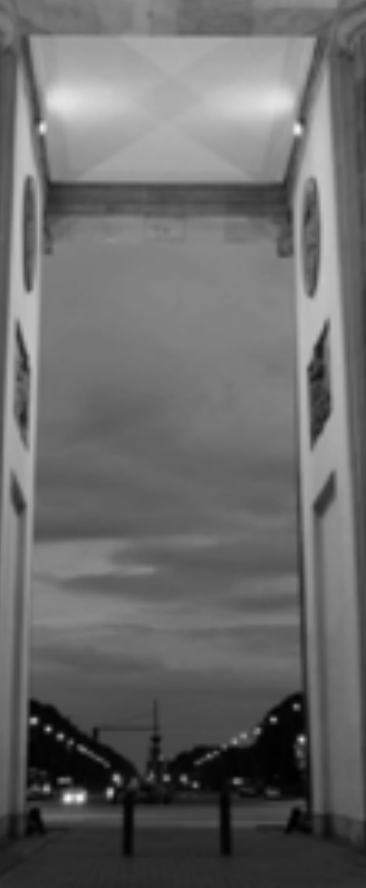

\section{MAIN CONGRESS}

Chronic Pain;

Neurological,

Cardiovascular,

Gastrointestinal \&

Urological Dysfunction; Neurorehabilitation \& more!

\section{VENUE \\ Estrel Hotel \\ Berlin, Germany \\ ABSTRACT DEADLINE \\ January 14, 2013}




\section{The latest in stroke research}

\section{Cerebirovascular Diseases}

Editor-in-Chief
M.G. Hennerici, Mannheim
Associate Editors
H. Adams, lowa City, lowa
L.B. Goldstein,
Durham, N.C.
J.-S. Kim, Seoul
Y. Kokubo, Osaka
M.M. Mehndiratta,
New Delhi

J.P. Mohr, New York, N.Y.

Y. Shinohara, Tokyo

N. Venketasubramanian, Singapore

Associate Co-Editor

S. Meairs, Mannheim
Official Journal of the European Stroke Conference (ESC)

Official Journal of the European Stroke Organization (ESO)

\section{Cerebrovascular Diseases}

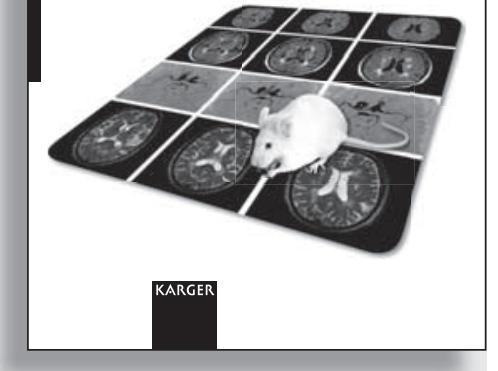

\section{More information at}

\section{www.karger.com/ced}

- Pay-per-View and Subscriber Access to Full Text

- Full Table of Contents

- Full Editorial Board

- Free Abstracts and Selected Articles

- Online Sample Issue

- Submission/Guidelines for Authors

- Subscription Details

- Free Alert Service

- Online Library Recommendation

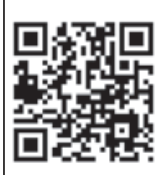

Cerebrovascular Diseases

2013: Volumes 35,36

6 issues per volume

Language: English

ISSN 1015-9770 (print)

ISSN 1421-9786 (online)

\section{Selected contributions}

- Interleukin-1 and Stroke: Biomarker, Harbinger of Damage, and Therapeutic

Target: Denes, A.; Pinteaux, E.; Rothwell, N.J.; Allan, S.M. (Manchester)

- Persistent Hyperglycemia at 24-48 h in Acute Hyperglycemic Stroke Patients Is

Not Associated with a Worse Functional Outcome: Ntaios, G.; Abatzi, C.;

Alexandrou, M.; Lambrou, D.; Chatzopoulos, S.; Egli, M.; Ruiz, J. (Lausanne);

Bornstein, N. (Tel-Aviv); Michel, P. (Lausanne)

- A New Image-Based Stroke Registry Containing Quantitative Magnetic

Resonance Imaging Data: Kim, D.-E. (Goyang); Park, K.-J. (Gimhae); Schellingerhout, D. (Houston, Tex.); Jeong, S.-W.; Ji, M.-G.; Choi, W.J. (Goyang); Tak, Y.-O.; Kwan, G.-H. (Gimhae); Koh, E.A. (Houston, Tex.); Noh, S.-M.; Jang, H.Y. (Goyang); Kim, T.-Y. (Gimhae); Jeong, J.-W. (Houston, Tex.); Lee, J.S. (Seoul); Choi, H.-K. (Gimhae)

- New Vessels after Stroke: Postischemic Neovascularization and Regeneration: Liman, T.G.; Endres, M. (Berlin)

- New Frontiers for Stroke Prevention in Atrial Fibrillation: Prasad, V.; Kaplan, R.M.; Passman, R.S. (Chicago, III.)

- The Ischemic Penumbra: Correlates in Imaging and Implications for Treatment of Ischemic Stroke. The Johann Jacob Wepfer Award 2011: Heiss, W.-D. (Cologne)

- Diffusion-Weighted Imaging for the Differential Diagnosis of Disorders Affecting the Hippocampus: Förster, A.; Griebe, M.; Gass, A.; Kern, R.; Hennerici, M.G.; Szabo, K. (Mannheim)
A rapidly-growing field, stroke and cerebrovascular research is unique in that it involves a variety of specialties such as neurology, internal medicine, surgery, radiology, epidemiology, cardiology, hematology, psychology and rehabilitation. Cerebrovascular Diseases is an international forum which meets the growing need for sophisticated, up-to-date scientific information on clinical data, diagnostic testing, and therapeutic issues, dealing with all aspects of stroke and cerebrovascular diseases. It contains original contributions, reviews of selected topics and clinical investigative studies, recent meeting reports and work-in-progress as well as discussions on controversial issues. All aspects related to clinical advances are considered, while purely experimental work appears if directly relevant to clinical issues. 


\section{Stereotactic and Functional Neurosurgery}

Historical Paper

347 A Narrative History of the International Society for Psychiatric Surgery: 1970-1983

Lipsman, N. (Toronto, Ont.); Meyerson, B.A. (Stockholm); Lozano, A.M. (Toronto, Ont.)

Review

356 DREZotomy in the Treatment of Cancer Pain: A Review Gadgil, N.; Viswanathan, A. (Houston, Tex.)

Technical Report

361 Securing Dual Ipsilateral Leads through a Single Burr Hole in Deep Brain Stimulation Surgery: Technical Note Potts, M.B.; Larson, P.S. (San Francisco, Calif.)

Clinical Studies

365 Gamma Knife Stereotactic Radiosurgery for Radiation-Induced Meningiomas

Kuhn, E.N.; Chan, M.D.; Tatter, S.B.; Ellis, T.L.

(Winston-Salem, N.C.)

370 Improved Dexterity after Chronic Electrical Stimulation of the Motor Cortex for Central Pain: A Special Relevance for Thalamic Syndrome

Nuti, C.; Vassal, F. (Saint-Etienne); Mertens, P.

(Saint-Etienne/Lyon); Lemaire, J.-J. (Clermont-Ferrand);

Magnin, M.; Peyron, R. (Saint-Etienne)

379 Long-Term Outcome of Anterior Thalamic Nucleus Stimulation for Intractable Epilepsy

Lee, K.J.; Shon, Y.M. (Seoul); Cho, C.B. (Gyeonggi-do)
386 Weight Change after Globus Pallidus Internus or Subthalamic Nucleus Deep Brain Stimulation in Parkinson's Disease and Dystonia

Mills, K.A.; Scherzer, R.; Starr, P.A.; Ostrem, J.L.

(San Francisco, Calif.)

394 Long-Term Effects of Deep Brain Stimulation for Essential Tremor with Subjective and Objective Quantification via Mailed-In Questionnaires de Oliveira, T.H.; Ginsberg, M.R.; Cooper, S.; Nowacki, A. (Cleveland, Ohio); Rezai, A. (Columbus, Ohio); Deogaonkar, M.; Machado, A.G. (Cleveland, Ohio)

Technology Report

401 Stereotactic Operations Using the O-Arm Katisko, J.P.A.; Kauppinen, M.T.; Koivukangas, J.P.; Heikkinen, E.R. (Oulu)

Letter to the Editor

410 Decrease in Blood Cortisol Corresponds to Weight Gain following Deep Brain Stimulation of the Subthalamic Nucleus in Parkinson's Disease

Růžička, E.; Nováková, L.; Jech, R.; Urgošík, D.; Růžička, F.; Haluzík, M. (Prague)

412 WSSFN Society News

413 ASSFN Society News

414 ESSFN The Mission

after 414 Contents Vol. 90, 2012 